Scientific Review - Engineering and Environmental Sciences (2019), 28 (4), 547-556

Sci. Rev. Eng. Env. Sci. (2019), 28 (4)

Przegląd Naukowy - Inżynieria i Kształtowanie Środowiska (2019), 28 (4), 547-556

Prz. Nauk. Inż. Kszt. Środ. (2019), 28 (4)

http://iks.pn.sggw.pl

DOI 10.22630/PNIKS.2019.28.4.50

Rima DHAHRI, Ines EZZINE, Mohammed GHANMI

Faculty of Sciences, University of Sciences of Tunis

\title{
An experimental study of selected Jurassic carbonate samples from north-eastern Tunisia
}

Key words: geotechnical test, aggregates, carbonates, Jurassic, Tunis-Zaghouane

\section{Introduction}

The industrial development of the outcrops in north-eastern Tunisia could represent an important economic driver for the country (Slim, Fredj \& Mohamed, 2016; Ameur, Hamzaoui-Azaza, Cheikha, Ahmed \& Gueddari, 2018). However, optimal development of these resources remains challenging due to the lack of accurate and comprehensive characterization and the pronounced presence of multi-scales heterogeneities.

The area of study (e.g. Tunis-Zaghouane area) is characterized from a structural point of view by the Zaghouane fault that exhibits a main NE-SW direction (Morgan, Grocott \& Moody, 1998; Jemmali, Souissi, Vennemann \& Carranza, 2011). In addition to this main fault, a series of multidirectional faults, strike-slip faults and overlaps coexist. Furthermore, the area is mainly com- posed of synclines and anclines with a particular distribution of anticlines.

The Tunis-Zaghouane area, from a mineralogical point of view, is considered to be one of the main reservoirs of clays, gypsum, carbonates and sands in Tunisia. Although several studies have thoroughly characterized the clays that are present in north-eastern Tunisia (Mahmoudi, Srasra \& Zargouni, 2008; Hajjaji et al., 2010; Souissi, Souissi \& Dandurand, 2010) only a limited number of studies have investigated its geotechnical potential for the construction industry.

Slim et al. (2016) performed a petrographical, mineralogical and geotechnical experimental characterization on selected samples from the southern part of north eastern Tunisia. More specifically, the samples were extracted from Jebels Bent Saidane, Bou Garnine Raous and Bridge of Fahs. The petrography showed that extracted samples are low porosity packstones. The mineralogical measurements confirmed that the main component is calcite (higher that 97\%) 
with traces of dolomite, quartz and clays. The geotechnical measurements through micro-Deval and Los Angeles confirmed that good quality aggregates could be provided from the quarries of the Tunis-Zaghouane area for concrete and road surfaces. However, the geotechnical measurements only considered a limited number of samples that were extracted from one location within the Tunis-Zaghouane area.

Ezzeiri and Hamdi (2018) investigated geotechnical properties of samples from Oust formation which is located in the Tunis-Zaghouane area. Measurements of elastic properties, porosity, and mineralogy were conducted in addition to scanning electron microscopy (SEM) image analysis. Results confirmed that the samples extracted from the Oust formation are mainly composed by calcite, with minor traces of quartz and periclase. Moreover, both water and helium porosity measurements showed a very compact behaviour with porosities of less than $0.5 \%$.

The objective of this paper is to provide a dataset of geotechnical measurements of selected samples that were locally extracted within the Tunis-Zaghouane area. First, the area of interest is presented with illustrations that were obtained from onsite field missions. Then, selected samples were subject to geotechnical characterization of water porosity, density and micro-Deval tests. Finally the obtained measurements were analysed and the synergies between the different samples is assessed.

\section{Geological description of the study area}

The area of study is located in north-eastern Tunisia and is extended through an area of $4,875 \mathrm{~km}^{2}$ with a width of $65 \mathrm{~km}$ and length of $75 \mathrm{~km}$. The two main cities that are present in the study area, are Tunis - the capital of the country, and Zaghouane. The distance between these cities is approximately $65 \mathrm{~km}$. The main outcrops of the Tunis-Zaghouane are the following: Jebel Mayana, Jebel Ressas, Jebel Oust, Jebel Hammam Jedidi, Jebel Hammam Zriba and Jebel Zaghouane. Several field missions to these outcrops took place between November and December 2018. The main objectives of these field trips were to observe the main geological features, generate illustrative material and extract representative samples for experimental geotechnical characterization. Figure 1 shows the north-eastern part of Tunisia, highlights the two main cities of the region and more particularly defines the locations of the structures that were studied and sampled. A geological overview of these formations is provided in the next paragraphs.

\section{Jebel Zaghouane}

Jebel Zaghouane is situated $50 \mathrm{~km}$ south of Tunis (Fig. 1) and is $1,295 \mathrm{~m}$ high. This structure is a part of the $\mathrm{Za}-$ ghouane massive, which is composed of Jebel Chegaga, Jebel El Kolhol and Jebel Azeiz. Jebel Zaghouane is characterized by its Jurassic outcrop and the NW-SE orientation of its layers. 


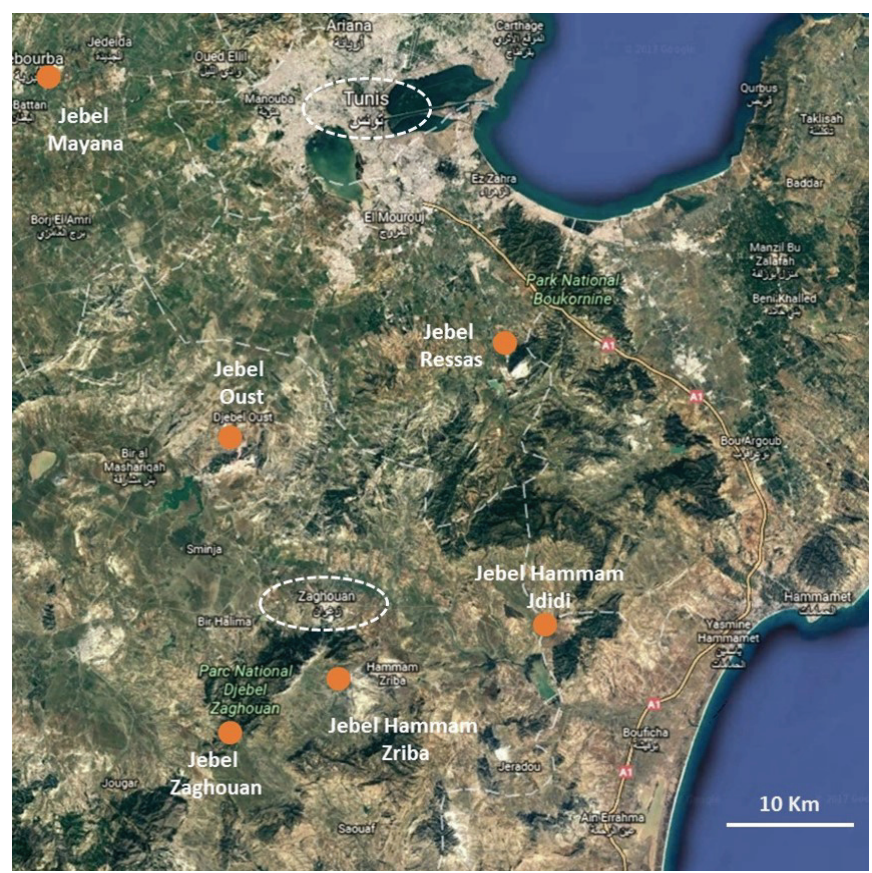

FIGURE 1. The area of study, the Tunis-Zaghouane area, which is located in north-eastern Tunisia. The main cities are highlighted in dashed white lines. The structures that were studied are highlighted with circles. There is a scale bar for indication of distances. This map was extracted from Google Earth (https://www.google.com/earth/)

\section{Jebel Ressas}

Jebel Ressas is located $30 \mathrm{~km}$ south of Tunis (Fig. 1). It is a structure of $3.5 \mathrm{~km}$ of length and $1.5 \mathrm{~km}$ of width. The quarry of Jebel Ressas contains significant carbonate deposits. Jebel Ressas consists of two major parts: Le Petit Ressas in the North and Le Grand Ressas in the South. In this structure Jurassic deposits, which are distributed sub-vertically, are mostly carbonates (Souissi, Souissi, Ghorbel, Munoz \& Courjault-Radé, 2015).

\section{Jebel Mayana}

Jebel Mayana is situated in the north of the governorate of Tunis, in Tebourba region (Fig. 1). The structure recorded important geological events which gen- erated neo-formations in addition to important fracturing and folding. Jurassic deposits are well developed in this area. Moreover, folds are significantly present in with a direction that varies from $\mathrm{E}-\mathrm{W}$, $\mathrm{N}-\mathrm{S}$ to N140 and N160.

\section{Jebel Hammam Zriba}

Jebel Hammam Zriba is located 68 $\mathrm{km}$ in the south of Tunis (Fig. 1). Its stratigraphic deposits are composed of limestone which are belonging to the Portlandian-early Eocene period. The structure is also characterized by important fracturing. Tectonic movements has resulted in the creation of a series of water connected fractures, which led to remarkable mineralization of calcite and 
aragonite. Furthermore, this site is well-known by its Triassic hot springs in addition its ore reserves such as zinc, barium and fluorine (Bouhlel, Fortune, Guilhaumou \& Touray, 1988; Djebbi, Chaabani, Font, Queralt \& Querol, 2017). Figure 2 illustrates the important fracturing and the mineralization that are observable in Jebel Hammam Zriba.

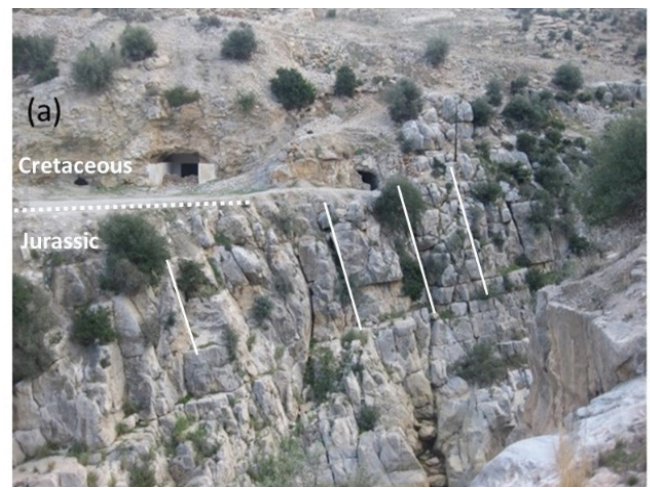

Jebel Oust is typically characterized by oncolites and ammonitico rosso facies.

\section{Material and methods}

\section{Samples}

Sampling of selected and representative rock material took place during the field missions. The main objective is

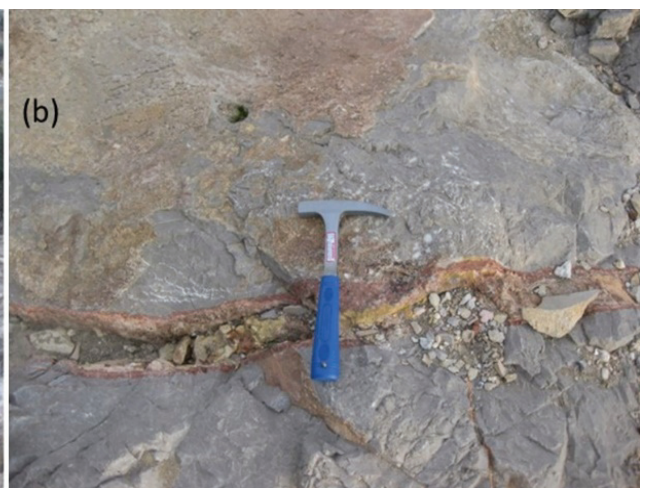

FIGURE 2. Jebel Hammam Zriba: a - N-S fractured limestone (continuous line). Photo illustrates two types of deposits that are separated by a dashed line. Jurassic deposits are shown below the line whereas Cretaceous deposits are above the line; $\mathrm{b}$ - mineralization within a fractured limestone

\section{Jebel Hammam Jedidi}

Jebel Hammam Jedidi is located about $50 \mathrm{~km}$ in the south-east of Tunis (Fig. 1). Like Jebel Hammam Zriba, Hammam Jedidi is known by its hot springs and by its ore reserves. Jurassic limestones, which are well developed in this structure, are subject to current development by onsite quarries.

\section{Jebel Oust}

Jebel Oust is situated $25 \mathrm{~km}$ in south-west of Zaghouane and is $396 \mathrm{~m}$ high. The distribution of the Jurassic deposits within the structures, follows the shape of E-W anticlines (Memmi, Donze, Combémorel \& Le Hegarat, 1989; Fredj, Melki \& Jridi, 2019). The limestone of to samples sufficient volume of porous media for geotechnical characterization through micro-Deval abrasion tests, porosity, and density and absorption measurements. From each structure, five parallelepiped-shaped samples $(30 \times 20 \times 10$ $\mathrm{cm})$ were extracted trough sawing and polishing. Figure 3 illustrates raw samples that were extracted and treated for experimental measurements.

\section{Micro-Deval abrasion tests}

According to the Tunisian standards of aggregates, dry micro-Deval values are considered acceptable if below 8\% for pavement foundation and if below $7 \%$ for the final coating (Slim et al., 2016). 

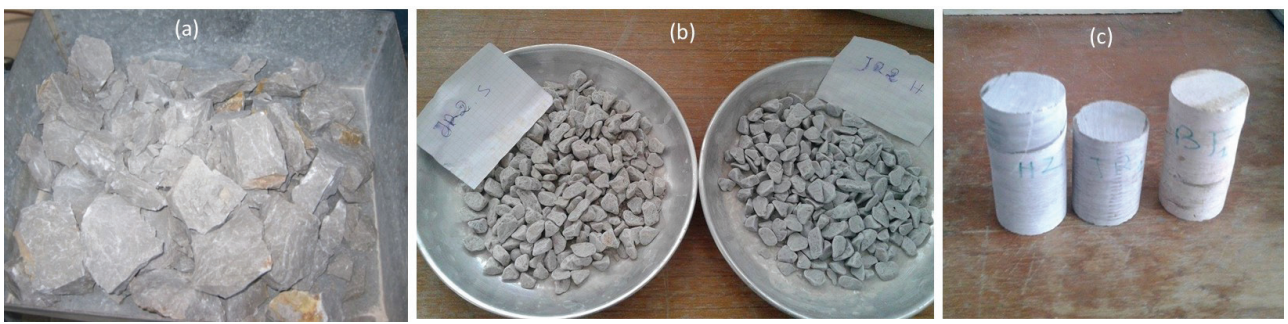

FIGURE 3. Samples: a - raw obtained after grinding; $b$ - crushed in preparation for the micro-Deval tests; c - cored for measurements of porosity, density and water absorption coefficients

In this study, both wet (MDH) and dry (MDS) measurements of micro-Deval abrasion loss were conducted to assess the geotechnical potential of the area (Rogers, 1998; Salah, Jemaï, Mezza \& Boughdiri, 2018). All samples were initially crushed using a jaw crusher then sieved with 14 and $10 \mathrm{~mm}$ sieves under vibrating conditions. Subsequently, the grains were loaded to the pre-cleaned rotating micro-Deval abrasion apparatus along with $5 \mathrm{~kg}$ of the abrasive charge and an initial mass of $500 \mathrm{~g}$ of $10-40 \mathrm{~mm}$ dry grains. For the wet tests, 2.51 of water was added to the mixture to ensure contact with water during the test. The rotating abrasion test took place at ambient conditions for $2 \mathrm{~h}$ with a rotating speed of $600 \mathrm{rpm}$. Subsequently, the grain samples were carefully collected, filtered and sieved with $1.6 \mathrm{~mm}$ sieve. Finally, the collected grains were dried in a vacuum oven for $36 \mathrm{~h}$ at $50^{\circ} \mathrm{C}$ then the final weight was measured using a mass balance. The micro-Deval loss percentage was then calculated based on the relative difference of the final and initial weights.

\section{Porosity, density and absorption}

The immersion in the water method has been used in order to measure porosity, density and absorption (McPhee, Reed \& Zubizarreta, 2015). These physi- cal parameters are inter-correlated and provide a description of the compaction of the rocks and their robustness as construction materials. The porosity test allows for determining the inter-grains connected voids within the porous medium. The density test illustrates the compaction capacities of the carbonates while absorption measurements translates the capacity of the rock for containing water. The carbonate sample was first dried in an oven at $50^{\circ} \mathrm{C}$ for $36 \mathrm{~h}$ and the dry weight was measured with a mass balance. Then, the sample was immersed in a graduated cylinder for $24 \mathrm{~h}$. The measurements of initial volume, final volume and weight of the saturated rock were obtained by direct reading on the cylinder (for the volumes) and by mass balance (for weight). The density was subsequently obtained by the ratio of the saturated weight over to the saturation or pore volume. Porosity was obtained through the ratio of final volume to the initial sample immersed bulk volume. The different volumes were measured by direct reading on the graduated cylinder. The absorption was calculated by dividing the weight of the water contained in the sample by the weight of the dry sample. 


\section{Results and discussions}

The table (p. 553) provides measurements of dry and wet micro-Deval, density, porosity and absorption coefficients for selected samples from the Tunis-Zaghounae area. From each formation of interest, five samples were subject to geotechnical measurements, representing a total number of 30 measurements.

It can be noticed that the variation of the density values are negligible as the average density obtained was $2.65 \mathrm{~g} \cdot \mathrm{cm}^{-3}$ with a standard deviation of 0.10 . This is in line with the density of carbonates in general and limestone in particular (Ahr, 2011). Moreover, the measured porosity values for all formations are relatively very low, with an average porosity (connected) of $1.31 \%$. This is also in agreement with the low porosity values from
Jebel Oust, which were reported by Ezzeiri and Hamdi (2018).

Figure 4 shows the relationship between the measured porosity and absorption coefficients. It can be noticed that the values of porosity and absorption are relatively low. A linear relationship between porosity and absorption can be observed. The different measured values can be fitted with a linear regression and with a slop of 0.36 (with a coefficient of determination). The absorption coefficient is therefore directly proportional to the porosity. Several studies have confirmed the linear relationship between porosity and absorption for different types of materials (Kearsley \& Wainwright, 2001; Zhou et al., 2017).

Figure 5 illustrates the variations of the wet micro-Deval with the dry micro-Deval measurements. As expected for

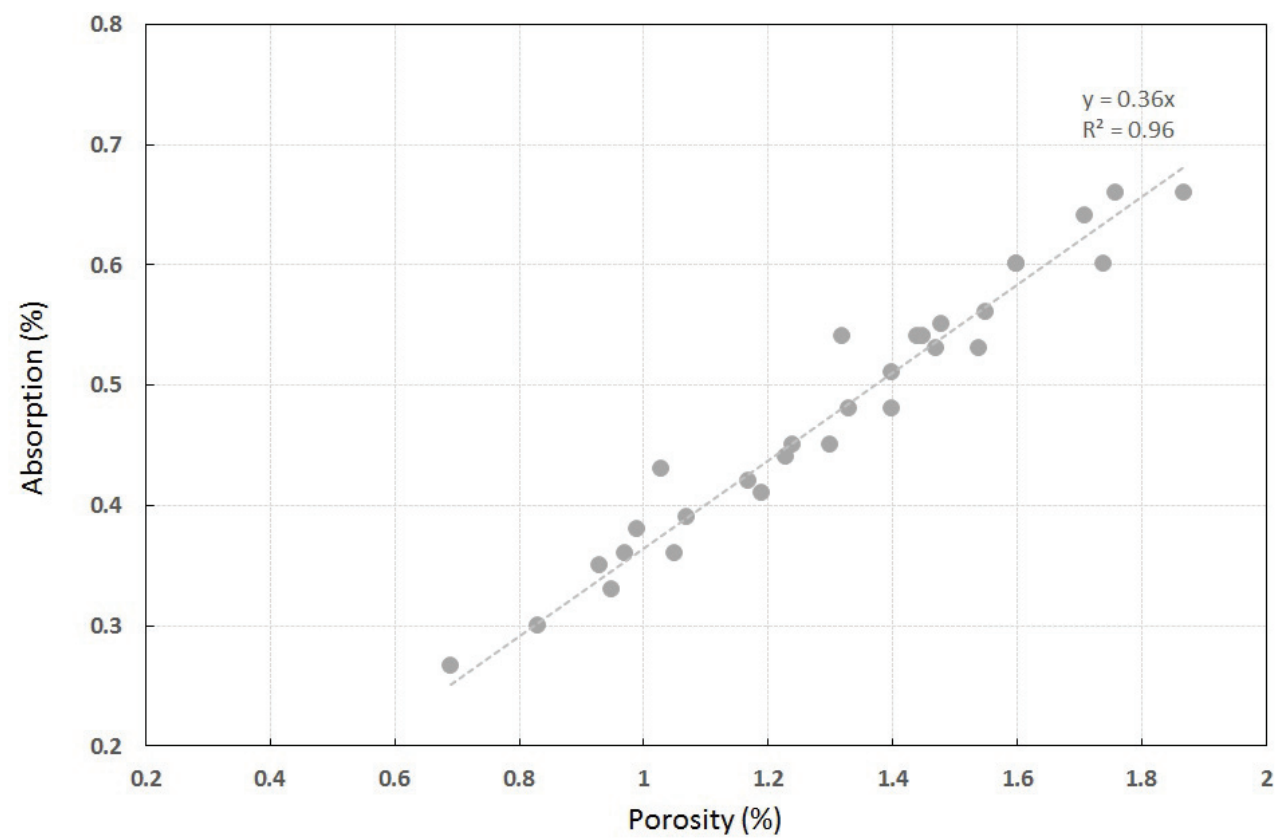

FIGURE 4. Relationship between measured connected porosity and water absorption coefficients for the selected samples from Tunis-Zaghouane area 
TABLE. Geotechnical measurements of wet (MDH) and dry (MDS) micro-Deval abrasion losses, density, porosity and water absorption coefficients

\begin{tabular}{|c|c|c|c|c|c|c|}
\hline No & Sample & $\begin{array}{c}\mathrm{MDH} \\
{[\%]}\end{array}$ & $\begin{array}{c}\mathrm{MDS} \\
{[\%]}\end{array}$ & $\begin{array}{l}\text { Density } \\
{\left[\mathrm{g} \cdot \mathrm{cm}^{-3}\right]}\end{array}$ & $\begin{array}{c}\text { Porosity } \\
{[\%]}\end{array}$ & $\begin{array}{c}\text { Absorption } \\
{[\%]}\end{array}$ \\
\hline 1 & Jebel Hammam Jedidi 1 & 7.17 & 10.10 & 2.71 & 0.95 & 0.33 \\
\hline 2 & Jebel Hammam Jedidi 2 & 7.82 & 13.50 & 2.33 & 1.03 & 0.43 \\
\hline 3 & Jebel Hammam Jedidi 3 & 8.01 & 12.62 & 2.72 & 0.69 & 0.27 \\
\hline 4 & Jebel Hammam Jedidi 4 & 7.49 & 11.80 & 2.60 & 0.99 & 0.38 \\
\hline 5 & Jebel Hammam Jedidi 5 & 7.04 & 11.01 & 2.70 & 0.93 & 0.35 \\
\hline 6 & Jebel Ressas 1 & 11.04 & 13.26 & 2.70 & 0.97 & 0.36 \\
\hline 7 & Jebel Ressas 2 & 6.78 & 12.02 & 2.72 & 1.17 & 0.42 \\
\hline 8 & Jebel Ressas 3 & 10.20 & 14.53 & 2.71 & 1.23 & 0.44 \\
\hline 9 & Jebel Ressas 4 & 6.94 & 9.85 & 2.51 & 0.83 & 0.30 \\
\hline 10 & Jebel Ressas 5 & 8.91 & 12.64 & 2.72 & 1.07 & 0.39 \\
\hline 11 & Jebel Zaghouane 1 & 5.28 & 21.28 & 2.70 & 1.60 & 0.60 \\
\hline 12 & Jebel Zaghouane 2 & 5.80 & 23.40 & 2.70 & 1.76 & 0.66 \\
\hline 13 & Jebel Zaghouane 3 & 4.75 & 19.15 & 2.65 & 1.44 & 0.54 \\
\hline 14 & Jebel Zaghouane 4 & 5.64 & 22.76 & 2.71 & 1.71 & 0.64 \\
\hline 15 & Jebel Zaghouane 5 & 4.91 & 19.70 & 2.70 & 1.48 & 0.55 \\
\hline 16 & Jebel Oust 1 & 9.79 & 18.23 & 2.43 & 1.60 & 0.60 \\
\hline 17 & Jebel Oust 2 & 10.67 & 19.87 & 2.51 & 1.74 & 0.60 \\
\hline 18 & Jebel Oust 3 & 8.90 & 16.58 & 2.70 & 1.45 & 0.54 \\
\hline 19 & Jebel Oust 4 & 11.45 & 21.32 & 2.70 & 1.87 & 0.66 \\
\hline 20 & Jebel Oust 5 & 8.12 & 15.13 & 2.63 & 1.32 & 0.54 \\
\hline 21 & Jebel Mayana 1 & 9.69 & 24.30 & 2.72 & 1.30 & 0.45 \\
\hline 22 & Jebel Mayana 2 & 10.46 & 26.24 & 2.72 & 1.40 & 0.48 \\
\hline 23 & Jebel Mayana 3 & 8.91 & 22.35 & 2.54 & 1.19 & 0.41 \\
\hline 24 & Jebel Mayana 4 & 11.53 & 28.91 & 2.55 & 1.54 & 0.53 \\
\hline 25 & Jebel Mayana 5 & 7.84 & 19.68 & 2.62 & 1.05 & 0.36 \\
\hline 26 & Jebel Hammam Zriba 1 & 5.51 & 15.26 & 2.60 & 1.40 & 0.51 \\
\hline 27 & Jebel Hammam Zriba 2 & 5.78 & 16.02 & 2.71 & 1.47 & 0.53 \\
\hline 28 & Jebel Hammam Zriba 3 & 5.23 & 14.49 & 2.70 & 1.33 & 0.48 \\
\hline 29 & Jebel Hammam Zriba 4 & 6.11 & 16.93 & 2.65 & 1.55 & 0.56 \\
\hline 30 & Jebel Hammam Zriba 5 & 4.90 & 13.58 & 2.74 & 1.24 & 0.45 \\
\hline
\end{tabular}

porous carbonates, the abrasion losses the samples that were extracted from are higher when the samples are exposed Jebel Hammam Jedidi and Jebel Resto water - all the wet micro-Deval are sas the differences between wet and dry above the identity line. Furthermore, for micro-Deval losses are less pronounced. 


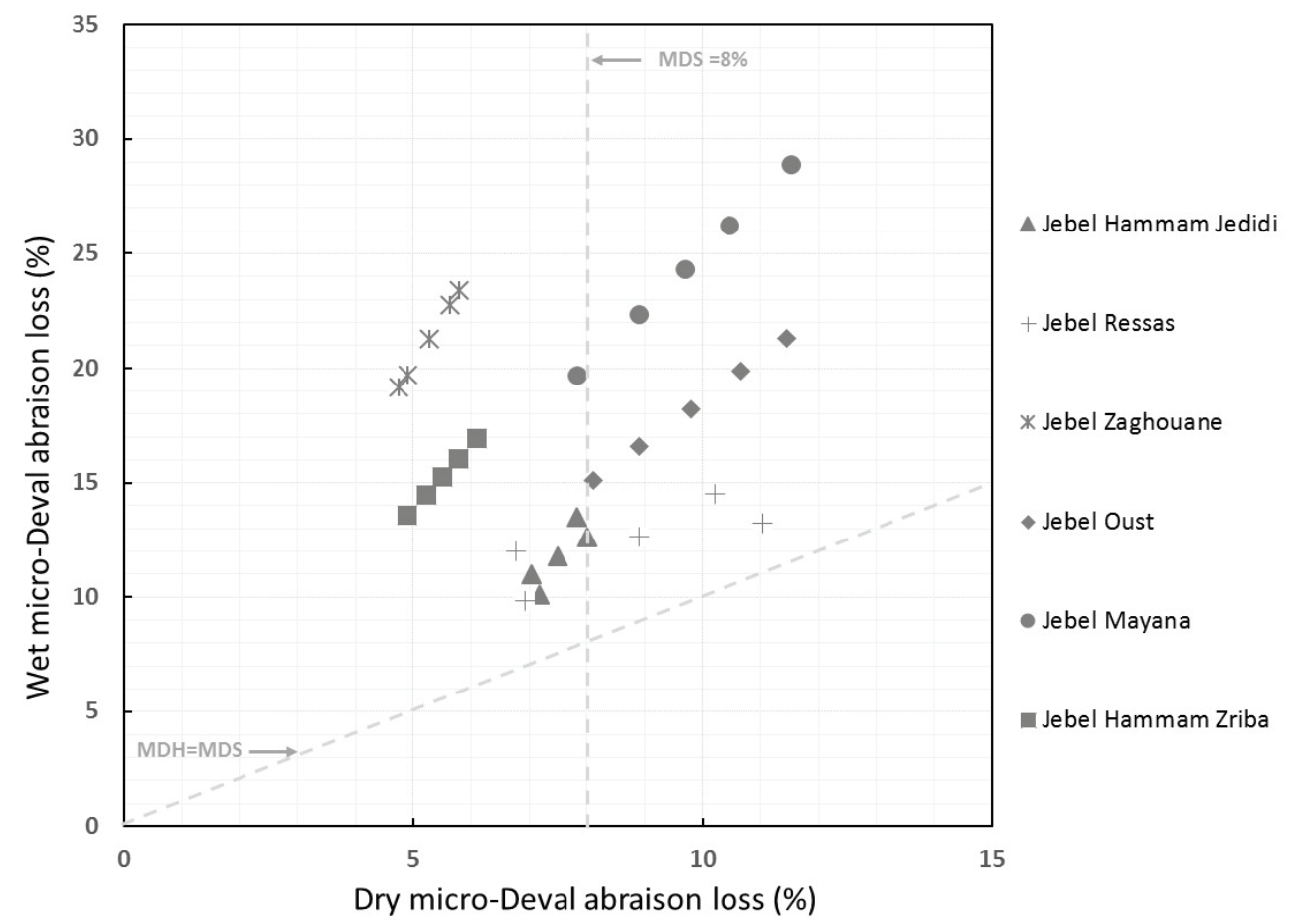

FIGURE 5. Relationship between measurements of wet (MDH) and dry (MDS) micro-Deval for samples extracted from Jebel Hammam Jedidi (triangle), Jebel Ressas (cross), Jebel Zaghouane (star), Jebel Oust (diamond). Jebel Mayana (circle) and Jebel Hammam Zriba (rectangle). Two lines are added: the line were $\mathrm{MDH}=\mathrm{MDS}$ and the one where $\mathrm{MDS}=8 \%$

This is an indication these outcrops could be eventually used as construction material in adaptable wet and dry weathers. It can be noticed that for all formations, wet micro-Deval is linearly increasing with the measurements of dry micro-Deval.

In addition, data on Figure 5 clearly shows that the samples from Jebel Zaghouane, Jebel Hammam Zriba and Jebel Bent Jedidi could be used for pavement foundation (dry micro-Deval below $8 \%$ ) whereas only samples extracted from Jebel Zaghouane and Jebel Hammam Zriba could also be used for final coating as well (dry micro-Deval below 7\%). For samples that were extracted from Jebel Hammam Jedidi and Jebel Oust, val- ues of dry micro-Deval are significantly higher than $8 \%$. Therefore, samples from these formation could not a priori be used for construction. Finally, the samples that were extracted from Jebel Ressas exhibit a large variation below and above $8 \%$.

\section{Conclusions}

This study provides a geotechnical characterization selected local samples from Tunis-Zaghouane area. The experimental results showed a negligible variation of densities, demonstrated a linear correlation between connected porosity 
and overall water absorption and identified promising resources for construction purposes. Experimental result of this study confirms that outcrops from Jebel Zaghouane, Jebel Hammam Zriba and Jebel Hammam Jedidi could be developed as construction materials. Full optimal development of the north-eastern resources in Tunisia - which will help the economy of the country - requires complementary testing and characterization.

\section{Acknowledgements}

The authors would like to thank the National Office of Mines of Tunisia for allowing this publication and would like to thank Mr. Faouzi Dhaha, Mr. Yassine Houla from the National Office of Mines for organizing the field missions and laboratory measurements.

\section{References}

Ahr, W.M. (2011). Geology of carbonate reservoirs: the identification, description and characterization of hydrocarbon reservoirs in carbonate rocks. Hoboken, NJ: John Wiley \& Sons.

Ameur, M., Hamzaoui-Azaza, F., Cheikha, L.B., Ahmed, T. \& Gueddari, M. (2018). A GIS mapping assessment of the suitability of the Oued Rmel aquifer for irrigation in the Zaghouan district (north-eastern Tunisia). Environmental Earth Sciences, 77(7), 292.

Bouhlel, S., Fortuné, J.P., Guilhaumou, N. \& Touray, J.C. (1988). Les minéralisations stratiformes à F-Ba de Hammam Zriba, Jebel Guébli (Tunisie nord orientale): l'apport des études d'inclusions fluides à la modélisation génétique. Mineralium Deposita, 23(3), 166-173 .

Djebbi, C., Chaabani, F., Font, O., Queralt, I. \& Querol, X. (2017). Atmospheric dust deposition on soils around an abandoned fluorite mine (Hammam Zriba, NE Tunisia). Environmental Research, 158, 153-166.

Ezzeiri, S. \& Hamdi, E. (2018). Characterization of limestone rocks to improve aggregate quality control. In 1st International Conference on Advances in Rock Mechanics - TuniRock 2018: Hammamet, Tunisia, 29-31.03.2018. Lisbon: International Society for Rock Mechanics and Rock Engineering.

Fredj, S.B., Melki, F. \& Jridi, K. (2019). Proposing rehabilitation scenarios for limestone quarries with 3D Modeling and 3D Print: Case of Jbel El Oust (Tunisian Atlas). In A. Kallel et al. (Eds.), Recent Advances in Geo-Environmental Engineering, Geomechanics and Geotechnics, and Geohazards (pp. 85-88). Cham: Springer.

Hajjaji, W., Hachani, M., Moussi, B., Jeridi, K., Medhioub, M., Lopez-Galindo, A., Rocha, F., Labrincha, J.A. \& Jamoussi, F. (2010). Mineralogy and plasticity in clay sediments from north-east Tunisia. Journal of African Earth Sciences, 57(1-2), 41-46.

Jemmali, N., Souissi, F., Vennemann, T.W. \& Carranza, E.J.M. (2011). Genesis of the Jurassic carbonate-hosted $\mathrm{Pb}-\mathrm{Zn}$ deposits of Jebel Ressas (North-Eastern Tunisia): evidence from mineralogy, petrography and trace metal contents and isotope $(\mathrm{O}, \mathrm{C}, \mathrm{S}$, $\mathrm{Pb}$ ) geochemistry. Resource Geology, 61(4), 367-383.

Kearsley, E.P. \& Wainwright, P.J. (2001). Porosity and permeability of foamed concrete. Cement and Concrete Research, 31(5), 805-812.

McPhee, C., Reed, J. \& Zubizarreta, I. (2015). Core analysis: A best practice guide. Elsevier.

Mahmoudi, S., Srasra, E. \& Zargouni, F. (2008). The use of Tunisian Barremian clay in the traditional ceramic industry: optimization of ceramic properties. Applied Clay Science, 42(1-2), 125-129.

Memmi, L., Donze, P., Combémorel, R. \& Le Hegarat, G. (1989). The transition from Jurassic to Cretaceous in northeast Tunisia: biostratigraphic details and distribution of facies. Cretaceous Research, 10(2), 137-151.

Morgan, M.A., Grocott, J. \& Moody, R.T. (1998). The structural evolution of the Zaghouan-Ressas structural belt, northern Tunisia. 
Geological Society, London, Special Publications, 132(1), 405-422.

Rogers, C. (1998). Canadian experience with the micro-Deval test for aggregates. Geological Society, London, Engineering Geology Special Publications, 13(1), 139-147.

Salah, I.B., Jemaï, M.B.M.B., Mezza, S. \& Boughdiri, M. (2018). Geotechnical study of the aptian limestone of the Kef Region, Northwestern Tunisia: Evaluation for industrial use. Open Journal of Geology, 8, 1084-1101.

Slim, B., Fredj, C. \& Mohamed, J. (2016). Characterization and evaluation of the potential of limestone jebels Bent Saidane, Bou Garnine Raous and Bridge of Fahs (North East Tunisia). Industrial Engineering Management, 5(192), 2169-0316.

Souissi, F., Souissi, R. \& Dandurand, J.L. (2010). The Mississippi Valley-type fluorite ore at Jebel Stah (Zaghouan district, north-eastern Tunisia): Contribution of REE and $\mathrm{Sr}$ isotope geochemistries to the genetic model. Ore Geology Reviews, 37(1), 15-30.

Souissi, R., Souissi, F., Ghorbel, M., Munoz, M. \& Courjault-Radé, P. (2015). Mobility of $\mathrm{Pb}, \mathrm{Zn}$ and $\mathrm{Cd}$ in a soil developed on a carbonated bedrock in a semi-arid climate and contaminated by $\mathrm{Pb}-\mathrm{Zn}$ tailing, Jebel Ressas (NE Tunisia). Environmental Earth Sciences, 73(7), 3501-3512.

Zhou, Z., Cai, X., Chen, L., Cao, W., Zhao, Y. \& Xiong, C. (2017). Influence of cyclic wetting and drying on physical and dynamic compressive properties of sandstone. Engineering Geology, 220, 1-12.

\section{Summary}

An experimental study of selected Jurassic carbonate samples from north-eastern Tunisia. The industrial development of the outcrops in the Tunis-Zaghouane area could represent an important economic driver for the country. The main structures are introduced and illustrated with onsite field observations. Moreover, samples which were extracted from the selected regions and are characterized based on measurements of porosity, water absorption and abrasion loss coefficients. The experimental results showed a negligible variation of densities, demonstrated a linear correlation between connected porosity and overall water absorption. In addition, experimental result confirms that outcrops from Jebel Zaghouane, Jebel Hammam Zriba and Jebel Hammam Jedidi could be developed as construction materials.

\section{Authors' address:}

Rima Dhahri

(https://orcid.org/0000-0002-2211-934X)

Iness Ezzine

(https://orcid.org/0000-0001-9648-9514)

Mohammed Ghanmi

(https://orcid.org/0000-0001-9475-1400)

University of Sciences of Tunis

Faculty of Sciences

Department of Geology

1060 Tunis Cedex

Tunisia

e-mail: rima.dhahri@yahoo.fr ezzineines82@gmail.com ghanmi.mohamed@gmail.com 